Arab Univ. J. Agric. Sci., Ain Shams Univ., Cairo, Egypt 28(2), 601-615, 2020

Website: http://ajs.journals.ekb.eg

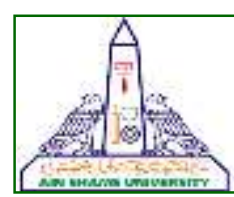

\title{
MONITORING OF COUNTERFEIT ABAMECTIN PESTICIDE PRODUCTS IN EGYPT
}

Gehad M. Khattab ${ }^{1^{*}}$, Walaa M. El-Sayed ${ }^{2}$, Attalla ${ }^{1}$ I.M. and Abdel Megeed ${ }^{2}$ M.I.

1- Central Agric. Pesticides Laboratory. Agric. Research Center, Ministry of Agric., Dokki, Giza, Egypt

2- Plant Protection Dept., Fac. of Agric., Ain Shams Univ., P.O. Box 68, Hadayek Shoubra 11241, Cairo, Egypt

*Corresponding author: gehad capl@yahoo.com

Received 17 November, 2019

Accepted 28 October, 2020

\section{ABSTRACT}

The monitoring of the counterfeit situation of a pesticide widely used in Egypt (abamectin) was done through the present study as seven samples of Abamectin formulations were collected from the Egyptian market. Packaging and labels were checked and analyzed by HPLC to determine the active ingredient content present in these samples. GC-MS and FTIR were used for additional analysis and detection of other active ingredients in the formulation.

Counterfeit pesticides were studied in Egypt by doing questionnaires for all workers in the pesticide system (farmer - trader - researchers in the pesticide field) and the results of these forms were analyzed to show the most dominant pesticides in Egypt, in addition to random purchase of pesticides from the Egyptian market and the most number of samples Is from (abamectin pesticide) (7 samples). To obtain this number of abamectin formulations, 58 different pesticide formulations (16 different active ingredients) were collected from the Egyptian markets, and the share of abamectin was 7 samples (one active substance), representing $12.1 \%$ of the total tested samples.

The obtained results showed that Examination of Packaging and indicated that three samples were not registered through Egyptian Agricultural Pesticides Committee thus representing $42.86 \%$ of the total tested samples. The non-registered products are Komaktin Gold Plus, Super Vertimic and Abamectine Strela. Three samples have registration number as other formulations already registered in Ministry of Agriculture which are Abamectin Super, Farmactine and Abamectin power. The last product (Tinam) has the correct registration number (no.1391) and it is the same number used to register it in Ministry of agriculture.

The percentage of the active ingredient in 5 samples was less than the acceptable limits, The samples were (Abamectin super, Komaktin Gold Plus, Abamectin Power, Super vertimic and Abamectine strela) active ingredient content was $1.416,0.64,1.01,0.2$ and $0.12 \%$ respectively. One sample (Farmactine) didn't contain Abamectin, and the sample (Tinam) was within the acceptable limits (1.53\%).

GC-MS used to determine the presence of any other materials or active ingredients within the samples. The result showed that Abamectin Super sample contains (Lambda cyhalothrin at R.t. 29.512 min), Farmactine sample contains (Fenpropathrin at R.t. $28.634 \mathrm{~min}$ ), Abamectin Power sample contains (Diazinon at R.t. 16.088 min and Cypermethrin at R.t. $26.554 \mathrm{~min}$ ) and Super Vertimic sample contains (Fenpropathrin at R.t. $23.916 \mathrm{~min}$ and Lambda cyhalothrin at R.t. $34.85 \mathrm{~min}$ ). Three products Komaktin Gold Plus, Tinam and Abamectine Strela didn't contain other active ingredients.

The physical properties of the studied samples before and after storage were determined through emulsion characteristic test and four samples (Abamectin super, Farmactine, Abamectin Power and Tinam) showed good emulsion characteristics before and after storage. Super vertimic and Abamectine strela samples showed poor emulsification characteristics before and after storage. Komaktin Gold Plus showed good emulsification before storage but poor emulsion characteristics after storage.

Keywords: Counterfeit Pesticides; Illegal Pesticides; Abamectin; Mass Spectroscopy; IR; Physical properties 


\section{INTRODUCTION}

The Agriculture Industry, which is the backbone of our economy, is facing multiple threats from the rise in counterfeit pesticides. There is rapid worldwide growth in counterfeit and illegally traded pesticides. These fake products are manufactured and sold by criminal groups. Based on the specificities of nations, the scope and scale of fake pesticides differ from store to store Depending on the circumstances of the countries. Counterfeit plant protection products can cause losses of crops and threaten public health, food trade and the environment.

In 2018, the global chemicals market for crop protection was worth USD 57.5 billion. It is projected to reach USD 68.82 billion by 2025, (Agrochemicals Market by Type - Global Trends \& Forecast to 2025) and is expected to increase by $4.7 \%$ during the forecast period (2019-2024). (Crop Protection Chemicals Market)

According to estimated data published by the European Crop Protection Association (ECPA, 2012), illegal and counterfeit pesticides account for over $10 \%$ of the worldwide market share of plant protection products. This percentage of market share in developing countries is projected to reach 20-30 percent (Karasali et al 2014). Based on ECPA statistics, 8-10 percent of plant protection products on the European market are estimated to be counterfeit.. Concerning the Polish market, the scale is estimated at $10-15 \%$. The main reason why this practice is widespread is financial benefits. Fake and illegal pesticides that contain materials that could pose a threat to the crops, environment, animals, and people.

Counterfeiting of pesticides and crop protection products has been a troublesome issue for the pesticide industry. Isolated instances are usually identified when a crop fails or the product does not work, and have been dealt with by individual companies, more recently with the growth of chemical manufacturing capability in countries such as India and China.

Pesticides are of great importance, necessity due to their use in agriculture and public health, therefore it is necessary to ensure the quality of these pesticides and their conformity with the standard specifications, especially since their active ingredients are no longer manufactured by their original producer once their patent period of 20 years has expired.
During the summer of 1976, thousands of cases of poisoning resulting from the use of malathion for malaria vector control were reported in Pakistan, that resulted in at least five deaths. Although these poisoning cases were primarily attributable to poor safety practices and hygiene, there was evidence that increased toxicity of poor-quality malathion also contributed to the poisonings. (Aldriage et al 1979).

The poor quality of malathion used in Pakistan had an S-methyl isomer content of $3.1 \%$ as well as significant amounts of the O,O,S-trimethylphosphorothioate and O,S,S-trimethyl phosphorodithioate impurities. Thus, the effect of such impurities may have had undesirable effects on human.

The first case of illegal pesticides in Europe occurred in Spain in the year 2000, when authorities uncovered unregistered pesticides without labels being imported from China (European Commission DG Health and Food Safety, 2015).

The nature and extent of counterfeit pesticides and illegal trade varies per market and can originate from many different sources in many different forms. The three main areas of illegal activity are:

1. Fakes: containing something from water or talc to diluted and obsolete or outdated products, including forbidden or banned materials Many fakes may provide a level of biological control, as they mostly contain anillegal and untested copy of the proprietary active substance.

2. Counterfeits: Advanced copies of branded products usually with high quality labeling and packaging. Most will contain a copy of the original active substance however; its biological efficacy is often less owing to high levels impurities of manufacturing and process by-products.

3. Illegal parallel imports: Parallel traded products substituted with illegal generic copies, repackaged and sold as original products. The repackaging puts the products at risk, allowing for contamination and the use of unacceptable packaging leads to a bad product that may cause harm to crops and pose risks to consumers. (Frederick M. Fishel, 2008).

\footnotetext{
Bad effects of illegal trade and counterfeit pesticides:

1. The health of consumers and farmers is at risk.

2. Environmental damage.

3. Economic damage to farmers.

4. Economic damage to governments.

5. Economic damage to the plant protection industry.
} 
All illicit products present a host of challenges to enforcement of trade regulations and controls (including taxation avoidance), industrial regulation and operations, farming operations, and consumer behavior and safety. Illicit goods also raise fundamental questions about legal and economic responsibility, social harm, and how illicit products and precursors are insinuated into legitimate distribution and supply chains. As mentioned, deleterious impacts of illicit pesticides are numerous and include damage to human and animal health, economic development and trade, agricultural production, natural resources and water supplies, including indigenous plants and wildlife.

Fighting counterfeit pesticides is a very complex task. We see there are more and more regulations related to pesticide use, but less and less attention towards implementing these regulations.

Pesticide producers are dedicating human and financial resources to fighting illegal trade and counterfeits. But they cannot succeed alone. Those responsible, and affected, need to lead governments, sellers and farmers. There is an immediate need for increased focus and improved human and financial resources.

The present work was directed to monitor the counterfeit situation of abamectin pesticide in Egypt.

\section{MATERIAL AND METHODS}

\section{Pesticides used}

The current work has been carried out to monitor the counterfeit situation of the abamectin formulations used in the agrochemicals market in Egypt. This was done through analyzing their active ingredient content by HPLC. GC-MS and FTIR were used to checking for other substances present in the products and finally, the physical properties of these samples was checked before and after storage using emulsion characteristic test.

In addition to this work, pesticide packages and labels were checked to monitor the position of counterfeit abamectin in Egypt.

Data on the active ingredient used for this work can be found in (Table 1) below.

\section{Sampling}

Seven pesticide formulations of emulsifiable concentrates of Abamectin were collected from several areas in the governorates of Cairo and Giza. Their trade names and concentrations on the label can be found in (Table 2) below.

\section{Quantitative analysis of active ingredients of the investigated pesticide formulations}

\subsection{Standard preparations of the tested pesti- cides.}

Standard solutions were prepared in methanol, at $400 \mathrm{ppm}$ for abamectin pesticides.

\subsection{Sample preparations of the tested pesticide formulations}

Weight of each tested formulation (Table 3) was placed into $25 \mathrm{ml}$ volumetric flask and completed to volume with methanol and shaken to dissolve the sample.

\section{Determination of active ingredients content of the tested pesticides by High Performance Liq- uid Chromatography}

HPLC equipment (Agilent technologies 1260 Infinit) was used with UV- detector. The column Eslips Plus C18, di.5 Mn and Len. 4.6 * $2.5 \mathrm{~mm}$. The wavelength detector at $235 \mathrm{~nm}$. The mobile phase was a mixture of acetonitril: methanol (70: 30$)$. The flow rate was $1.3 \mathrm{ml} / \mathrm{min}$.

\section{Determination of other materials present in the formulation}

\subsection{Gas Chromatography- Mass Spectroscopy}

A stock solution (4000 ppm) of formulation samples was prepared in $(25 \mathrm{ml})$ methanol. The GC-MS analysis was performed with an Agilent $7890 \mathrm{~B}$, gas chromatograph equipped with a mass spectrometric detector (MSD) model Agilent 5977 A. A fused silica capillary column $(30 \mathrm{~m} \times 0.25 \mathrm{~mm}$ HP-5-0.25 micron -60 to $325^{\circ} \mathrm{C}$ ) was used. Samples were injected under the following conditions:

Helium as carrier gas at a flow rate of $1.0 \mathrm{ml} / \mathrm{min}$, pulsed split mode, split ratio (10:1), split flow 10 $\mathrm{ml} / \mathrm{min}$. The solvent delay was $4 \mathrm{~min}$ and $1 \mu$ l volume was injected. Column temperature was maintained at $50^{\circ} \mathrm{C}$, for $0.5 \mathrm{~min}$ then programmed at $10^{\circ} \mathrm{C} / \mathrm{min}$ to $190^{\circ} \mathrm{C}$ followed by $10^{\circ} \mathrm{C} / \mathrm{min}$ ramp to $210^{\circ} \mathrm{C}$ for 1 min followed by $10^{\circ} \mathrm{C} / \mathrm{min}$ ramp to $300^{\circ} \mathrm{C}$ and held for $2 \mathrm{~min}$. Total analysis time was $29.5 \mathrm{~min}$. Injector port temperature was set at $280^{\circ} \mathrm{C}$.

Wiley mass spectral data base was used in the identification of the separated peaks. 
Table 1. Abamectin data - Pesticide Manual (2003)

\begin{tabular}{|c|c|}
\hline Common name & Abamectin \\
\hline Chemical class & Avermectin \\
\hline IUPAC name & 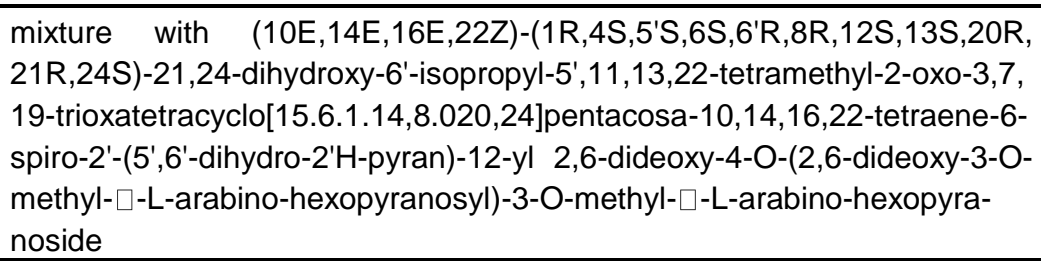 \\
\hline Molecular formula & $\mathrm{C}_{48} \mathrm{H}_{72} \mathrm{O}_{14}$ \\
\hline Chemical structure & (i) $\mathrm{R}=-\mathrm{CH}_{2} \mathrm{CH}_{3}$ (avermectin $\left.\mathrm{B}_{1 \mathrm{a}}\right)$ \\
\hline Molecular weight & 873.1 \\
\hline Activity & $\begin{array}{l}\text { Control of motile stages of mites, leaf miners, suckers, Colorado beetles, } \\
\text { etc. on ornamentals, cotton, citrus fruit, pome fruit, nut crops, vegetables, } \\
\text { potatoes, and other crops. Application rates are } 5.6 \text { to } 28 \mathrm{~g} / \mathrm{ha} \text { for mite con- } \\
\text { trol, } 11 \text { to } 22 \mathrm{~g} / \mathrm{ha} \text { for control of leaf miners. Also used for control of fire } \\
\text { ants. }\end{array}$ \\
\hline
\end{tabular}

Table 2. Products collected from the market for testing.

\begin{tabular}{|l|c|c|}
\hline \multicolumn{1}{|c|}{ Trade Name } & Active Ingredient & $\begin{array}{c}\text { Suggested Abamectin } \\
\text { content on the label }\end{array}$ \\
\hline Abamectin Super EC & Abamectin & $1.8 \%$ \\
Farmactine EC) & Abamectin & $1.8 \%$ \\
Komaktin Gold Plus EC & Abamectin & $1.8 \%$ \\
Abamectin Power EC & \& P.M.O & $\& 5 \%$ \\
Super Vertimic EC & Abamectin & $1.8 \%$ \\
Tinam EC & Abamectin & $1.8 \%$ \\
Abamectine Strela EC & Abamectin & $1.8 \%$ \\
\hline
\end{tabular}


Table 3. Weights for each sample prepared for testing

\begin{tabular}{|c|c|}
\hline Trade Name & $\begin{array}{c}\text { Weight (gm)/ 25 } \\
\text { ml }\end{array}$ \\
\hline Abamectin super (1.8\% EC) & 0.510 \\
Farmactine (1.8\% EC) & 0.490 \\
Komaktin Gold Plus (6.8\% & 0.560 \\
EC) & 0.510 \\
Abamectin Power (1.8\% EC) & 0.290 \\
Super Vertimic (1.8\% EC) & 0.497 \\
Tinam (1.8\% EC) & 0.465 \\
Abamectine Strela (1.8\% \\
EC)
\end{tabular}

\subsection{Infrared spectroscopy}

The samples were analyzed using Fourier transform infrared (FTIR) model (AVATAR 330) FT-IR Thermo Nicollet. Samples were examined between salt plates usually without a spacer. Pressing a sample between flat plates produces a film of $0.01 \mathrm{~mm}$ or less in thickness, the plates were held together by capillarity. Samples of 1-10 mg were required to produce a satisfactory spectrum.

IR spectra were recorded $(\mathrm{KBr})$ by a pye Unicam SP-1000 Spectrophotometer $\left(u\right.$ max in $\left.\mathrm{cm}^{-1}\right)$. According to Spectrometric identification of organic compounds, fifth edition, infrared spectrometry, chapter three, 1991-a).

6. Determination of emulsion characteristics of the investigated formulations before and after accelerated storage test

\subsection{Accelerated storage procedure (CIPAC MT 46.3).}

The formulations were stored in a glass bottle in an oven at $54 \pm 2^{\circ} \mathrm{C}$ for 14 days according to CIPAC MT 46.3 and the emulsification test was performed on the samples before and after storage to examine its physical properties.

\subsection{Preparation of standard water}

CIPAC MT 18.1 (1995), MT 18.3 Non-CIPAC Standard Waters, 18.3.1 WHO Standard Hard Water, (342 ppm hardness) were used in all testes of physical properties.
Calcium chloride $\mathrm{CaCl}_{2}$ (0.304 g) and magnesium chloride $\mathrm{MgCl}_{2}$. $6 \mathrm{H}_{2} \mathrm{O}(0.139 \mathrm{~g})$ were dissolved in distilled water and made up to $1000 \mathrm{ml}$.

\subsection{Emulsion stability evaluation for abamectin formulations (EC)}

The test was carried out according to CIPAC MT 36.3 (1995) where $5 \mathrm{ml}$ of the formulation was added to $95 \mathrm{ml}$ of standard water (in cylinder 100 $\mathrm{ml}$ ), the cylinder was stoppered then inverted once and left to stand for 30 seconds. Then the cylinder was inverted 10 times and left to stand at $30^{\circ} \mathrm{C} \pm$ $2^{\circ} \mathrm{C}$ for $30 \mathrm{~min}$ in a water bath. Any separated materials, volume of free oil, froth, cream, or solid matter present, if any, were recorded at the end of the 30 min period.

\section{RESULTS AND DISCUSSION}

Abamectin formulations of seven samples were collected from seven Egyptian markets then analyzed by HPLC to determine their active ingredient content. GC-MS and FTIR were used to determine the presence of other ingredients within the formulation and the physical properties of the studied products were also considered before and after storage using emulsion characteristics test.

\section{Abamectin formulation labels}

Table (4) shows the recorded data on labels of seven Abamectin formulations collected from different markets of Cairo and Giza. Examination of tabulated data indicated that three samples were not registered through Egyptian Agricultural Pesticides Committee from seven samples are the total tested samples. The non-registered products are Komaktin Gold Plus, Super Vertimic and Abamectine Strela. Three samples have registration number as other formulations already registered in Ministry of Agriculture which are Abamectin Super, Farmactine and Abamectin power. The last product (Tinam) has the correct registration number (no.1391) and it is the same number used to register it in Ministry of agriculture.

\section{Physical Properties of Abamectin formula- tions}

Emulsion test was performed before and after storage of the abamectin formulations Samples were stored in a glass bottle in oven at $54 \pm 2^{\circ} \mathrm{C}$ for 14 days. 


\begin{tabular}{|c|c|c|c|c|c|c|c|c|}
\hline \multirow{7}{*}{ 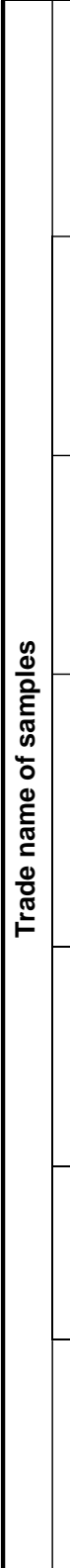 } & 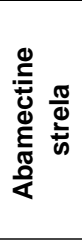 & నิ & 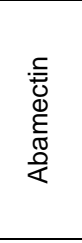 & $\stackrel{\circ}{\stackrel{\circ}{\infty}}$ & 㞻 & 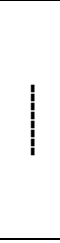 & 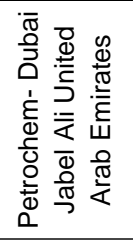 & 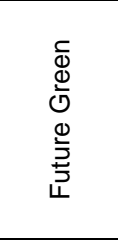 \\
\hline & 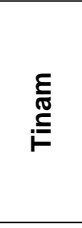 & চ্ল্ণ & 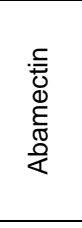 & $\stackrel{\circ}{\stackrel{\circ}{\circ}}$ & U & 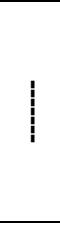 & 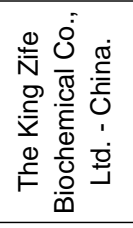 & 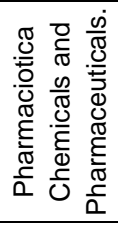 \\
\hline & 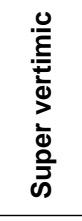 & 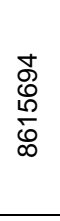 & 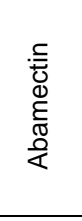 & @̊ & O & 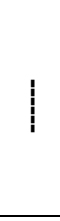 & 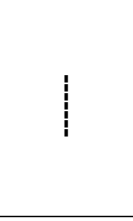 & 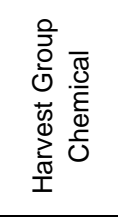 \\
\hline & 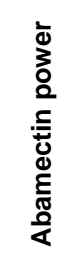 & ণ্ & 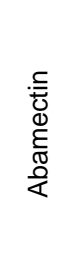 & $\stackrel{\circ}{\stackrel{\circ}{\circ}}$ & O & 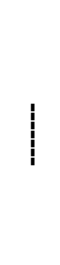 & 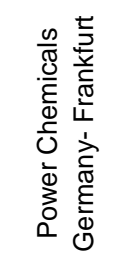 & 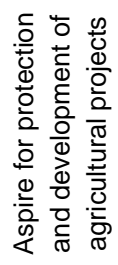 \\
\hline & 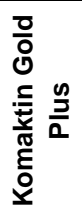 & 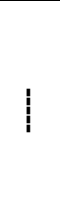 & 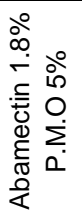 & $\begin{array}{l}\stackrel{0}{0} \\
\infty \\
0\end{array}$ & U্ய & 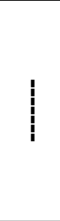 & 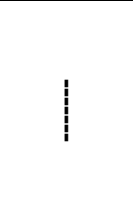 & 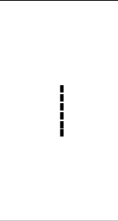 \\
\hline & 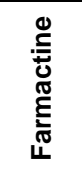 & $\begin{array}{l}\& \\
\&\end{array}$ & 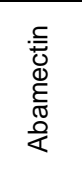 & $\stackrel{\circ}{\stackrel{\circ}{\circ}}$ & 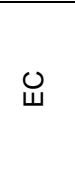 & 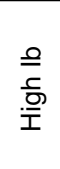 & 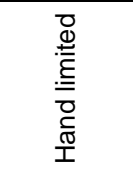 & 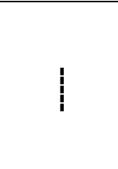 \\
\hline & 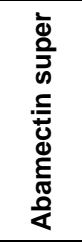 & $\underset{⿱}{\stackrel{N}{\sim}}$ & 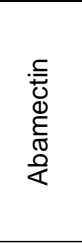 & $\stackrel{\circ}{\stackrel{\circ}{\Gamma}}$ & O & & 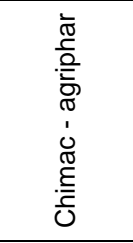 & 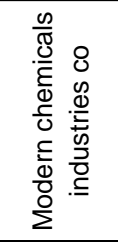 \\
\hline & $\underset{\Phi}{\Xi}$ & 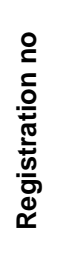 & 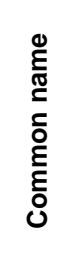 & 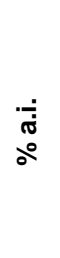 & 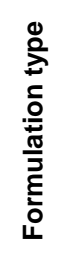 & 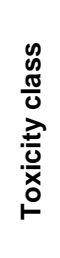 & 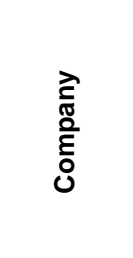 & 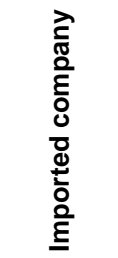 \\
\hline
\end{tabular}




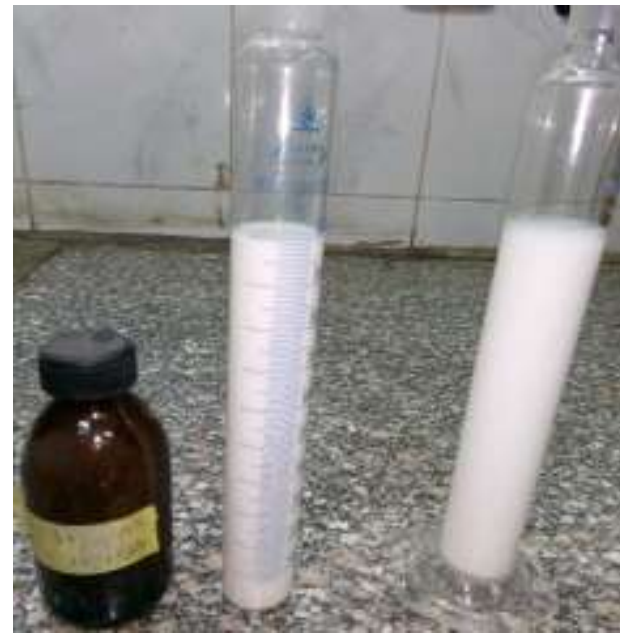

The emulsification test before and after storage conforms to specifications.

Fig. 1. Emulsion test before and after storage of Abamectin super.
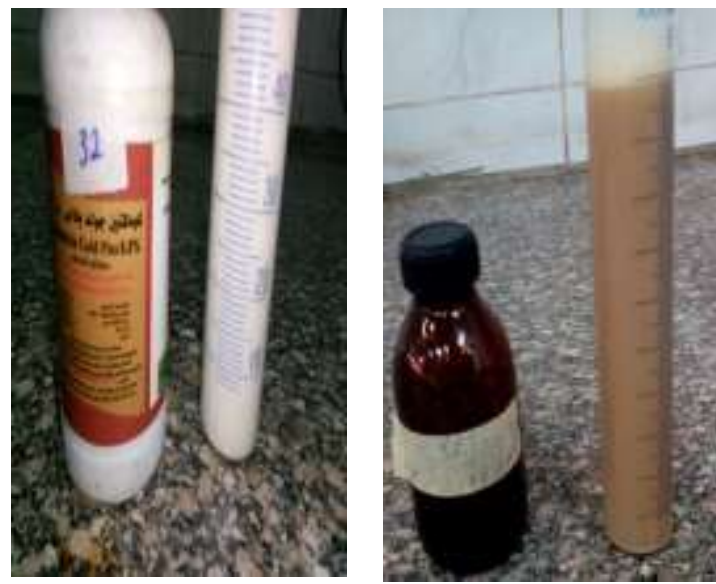

The emulsification test before conforms to specifications but after storage doesn't conform to specifications (Sample color changed) (Volume of Sediment is less than $\mathbf{2} \mathbf{~ m l}$ )

Fig. 3. Emulsion test before and after storage of Komaktin Gold Plus.

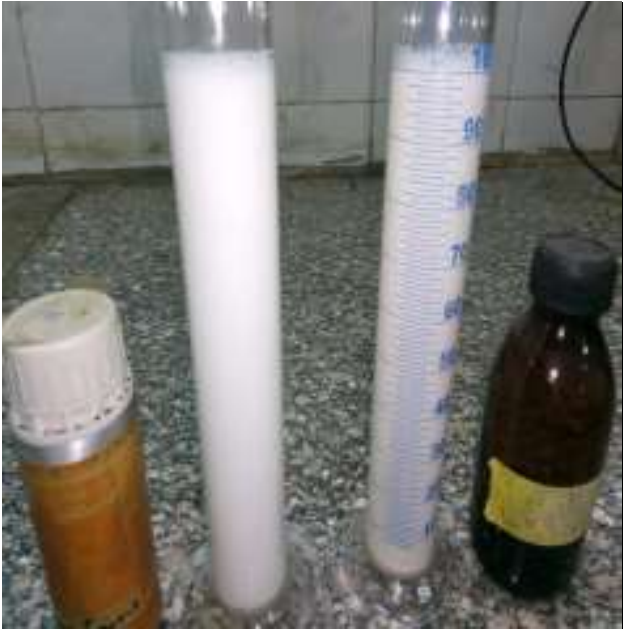

The emulsification test before and after storage conforms to specifications.

Fig. 2. Emulsion test before and after storage of Farmactine

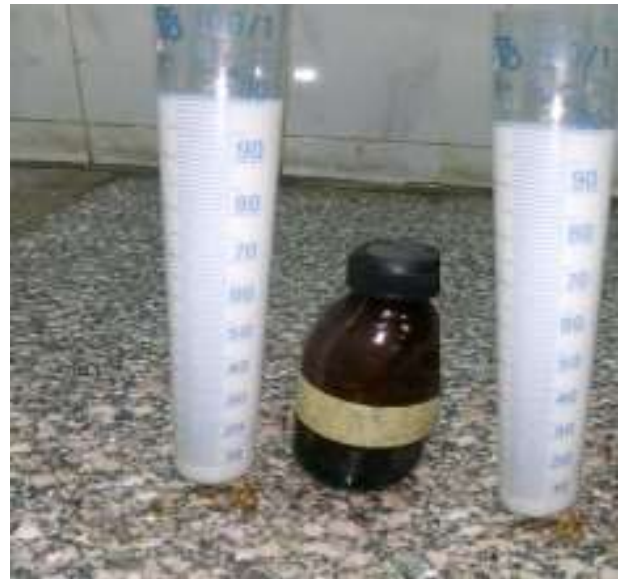

The emulsification test before and after storage conforms to specifications.

Fig. 4. Emulsion test before and after storage of Abamectin power. 

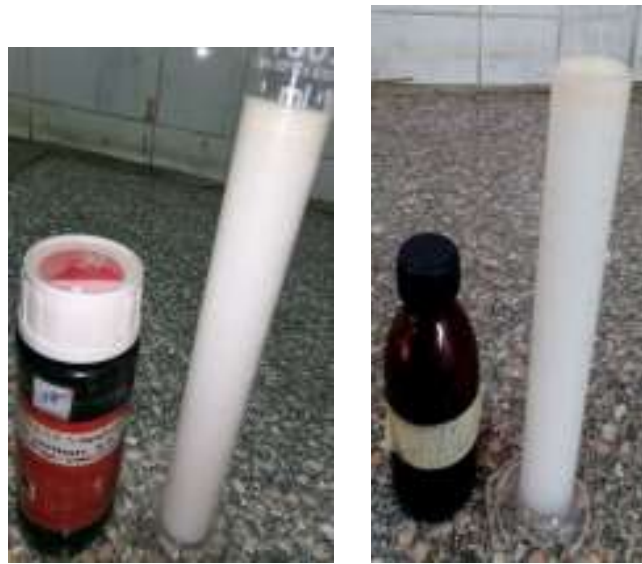

The emulsification test before and after storage doesn't conform to specifications (Volume of Sediment/cream layer is more than $2 \mathrm{ml}$ )

Fig. 5. Emulsion test before and after storage of Super vertimic.

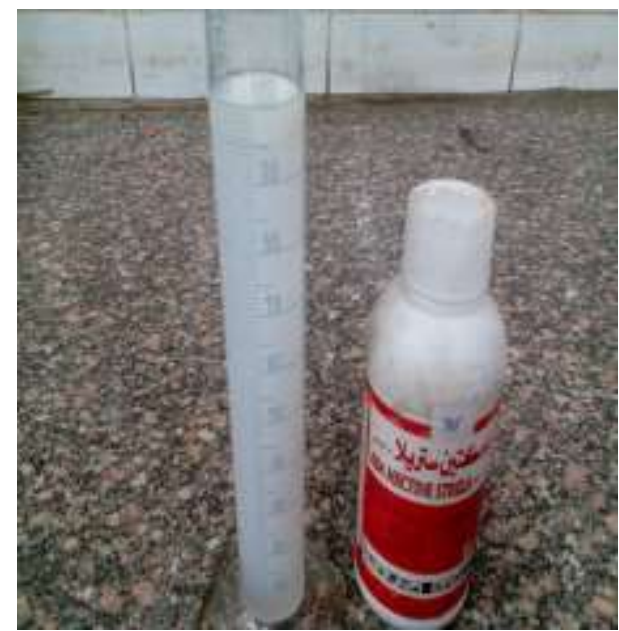

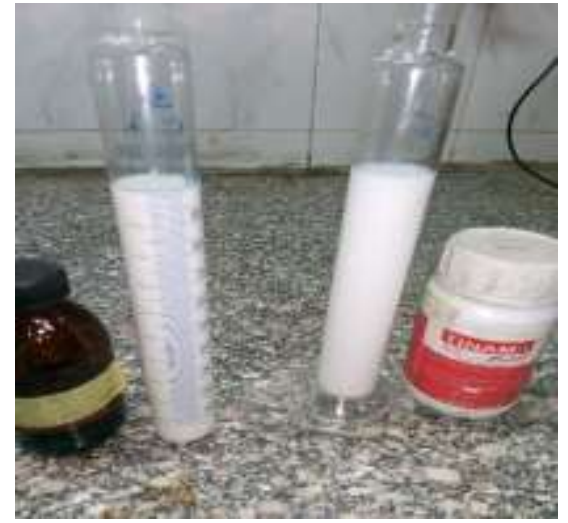

The emulsification test before and after storage conforms to specifications

Fig. 6. Emulsion test before and after storage of Tinam.

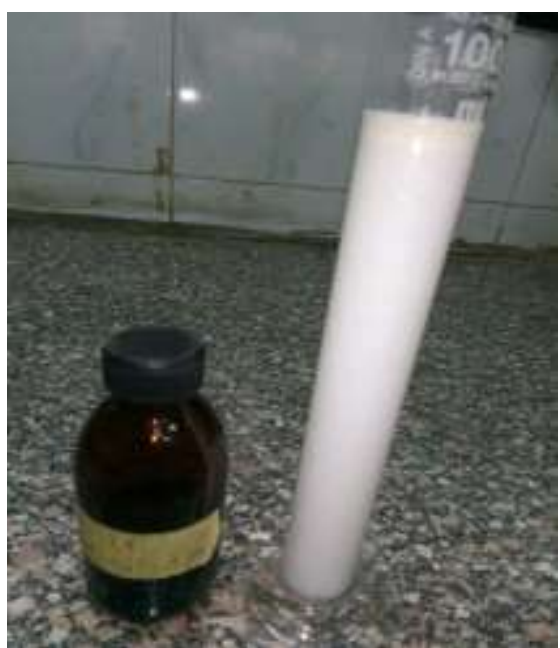

The emulsification test before and after storage doesn't conform to the specifications (Volume of Sediment/cream layer is more than $2 \mathrm{ml}$ )

Fig. 7. Emulsion test before and after storage of Abamectine strela 
The results indicated that 4 samples (Abamectin super, Farmactine, Abamectin Power and Tinam) showed good emulsification characteristics before and after storage. Super vertimic and Abamectine strela samples showed poor emulsification characteristics before and after storage. Komaktin Gold Plus showed good emulsification before storage but poor emulsion characteristics after storage.

\section{Determination of active ingredients content of Abamectin formulations by HPLC.}

The percentage of the active ingredient in 5 samples was less than the acceptable limits (+/$15 \%$ ). The samples (Abamectin super, Komaktin Gold Plus, Abamectin Power, Super vertimic and Abamectine strela) active ingredient content was $1.416,0.64,1.01,0.2$ and $0.12 \%$ respectively. One sample (Farmactine) didn't contain Abamectin, and the sample (Tinam) was within the acceptable limits. Results can be summarized in the Table (5) below:

Table 5. Assay for samples of pesticides using HPLC

\begin{tabular}{|l|c|}
\hline \multicolumn{1}{|c|}{ Trade Name } & $\begin{array}{c}\text { Assay (\% active } \\
\text { ingredient) }\end{array}$ \\
\hline Abamectin Super (1.8\%). & 1.416 \\
Komaktin Gold Plus (1.8\%). & 0.64 \\
Abamectin Power (1.8\%). & 1.01 \\
Super Vertimic (1.8\%). & 0.2 \\
Abamectine Strela (1.8\%). & 0.12 \\
Farmactine (1.8\%). & 0 \\
Tinam (1.8\%). & 1.53 \\
\hline
\end{tabular}

4. Determination of other materials present in the samples

\subsection{GC-MS Analysis}

Samples were analyzed by GC-MS to determine the presence of any other materials or active ingredients within the samples.

Abamectin Super sample contains (Lambda cyhalothrin at R.t. $29.512 \mathrm{~min}$ ), Farmactine sample contains (Fenpropathrin at R.t. $28.634 \mathrm{~min}$ ), Abamectin Power sample contains (Diazinon at R.t. $16.088 \mathrm{~min}$ and Cypermethrin at R.t. 26.554 min) and Super Vertimic sample contains (Fenpropathrin at R.t. $23.916 \mathrm{~min}$ and Lambda cyhalothrin at R.t. $34.85 \mathrm{~min}$ ).

Three products Komaktin Gold Plus, Tinam and Abamectine Strela didn't contain other active ingredients.

\subsection{Identification of Abamectin by FTIR}

FTIR analysis of Abamectin formulations was performed and the characteristic peaks were tentatively identified in the following Figs. $(16,17,18,19$, 20, 21 and 22).

The different functional group revealed the following range wave number for sample as indicated in Table (6). It was noted that certain parent function groups are in range in all products, while some other bands were appeared such as ( $\mathrm{C} \equiv \mathrm{N}$ stretching) in samples Abamectin Super, Farmactine and Abamectin Power. In samples Abamectin super and Super Vertimic (C-F) appeared at 1387 and 1377 respectively.

Counterfeiting has been reported in the form of absence of the active ingredient, wrong active ingredient. Active ingredient, fake packaging and contamination with unexpected substances (Karasali. 2015). The result showed that, the absence of the active ingredient in sample Farmactine. The insufficient active ingredient in samples Komaktin Gold Plus, Abamectin Power, Super vertimic and Abamectine strela. The packaging in samples Abamectin super, Farmactine, Komaktin Gold Plus, Abamectin power, Super vertimic and Abamectine strela. The contamination with unexpected substances in samples samples Abamectin super, Farmactine, Abamectin power and Super vertimic. 


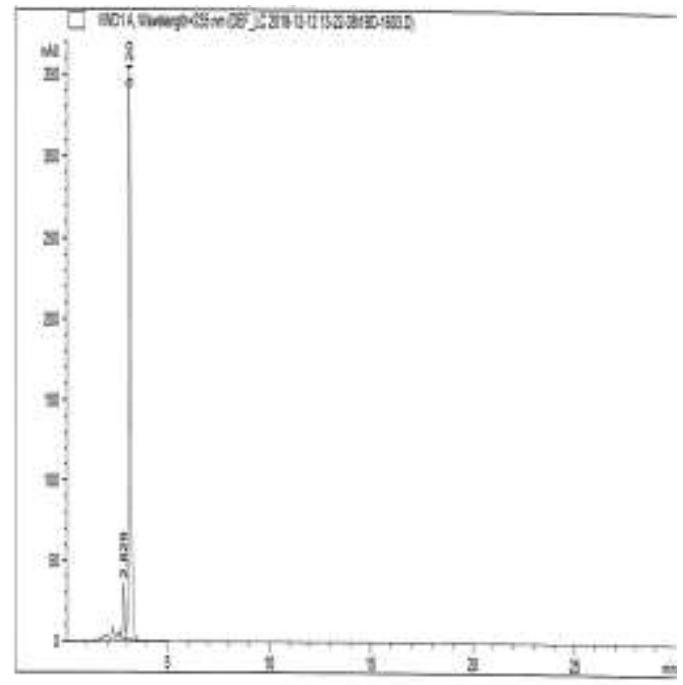

Fig. 8. HPLC Chromatogram of Abamectin St.

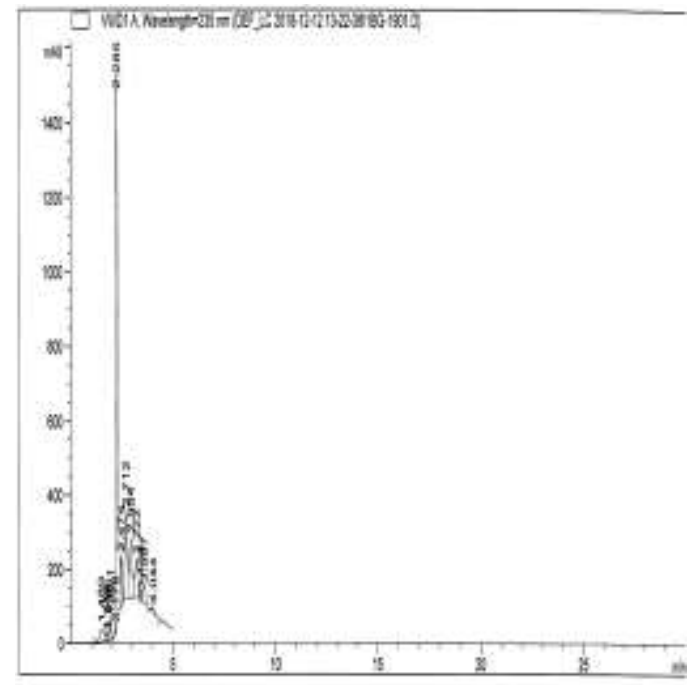

$\%$ a. $\mathbf{i}=$ zero

Fig. 10. HPLC Chromatogram of Farmactine.

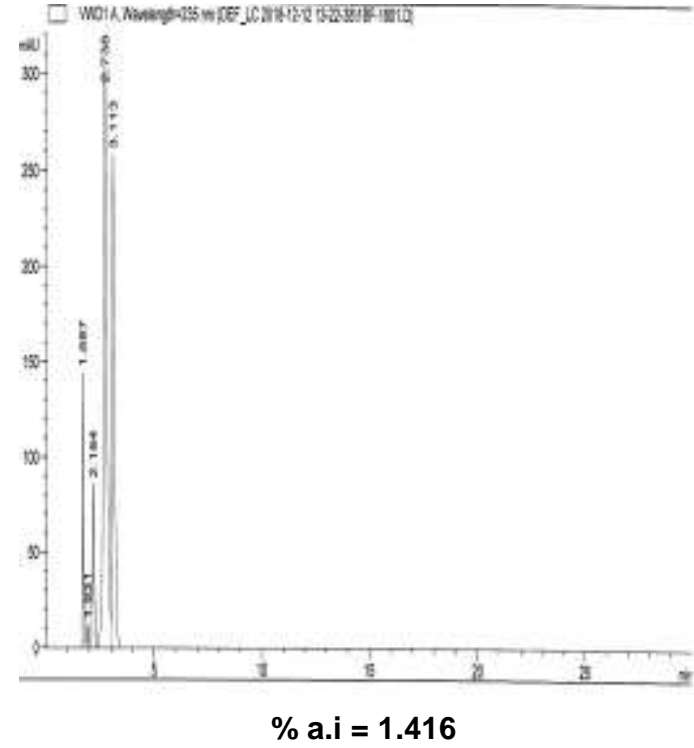

Fig. 9. HPLC Chromatogram of Abamectin super.

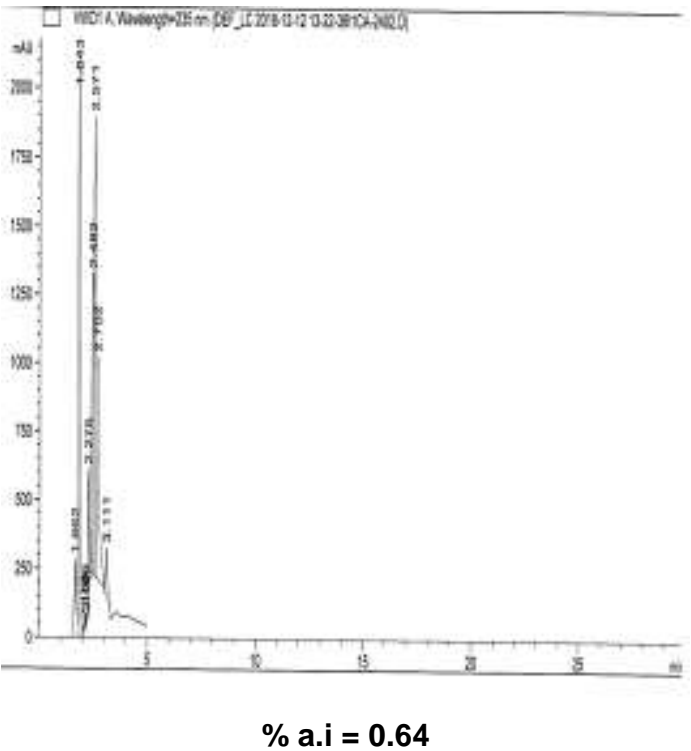

Fig. 11. HPLC Chromatogram of Komaktin Gold Plus. 

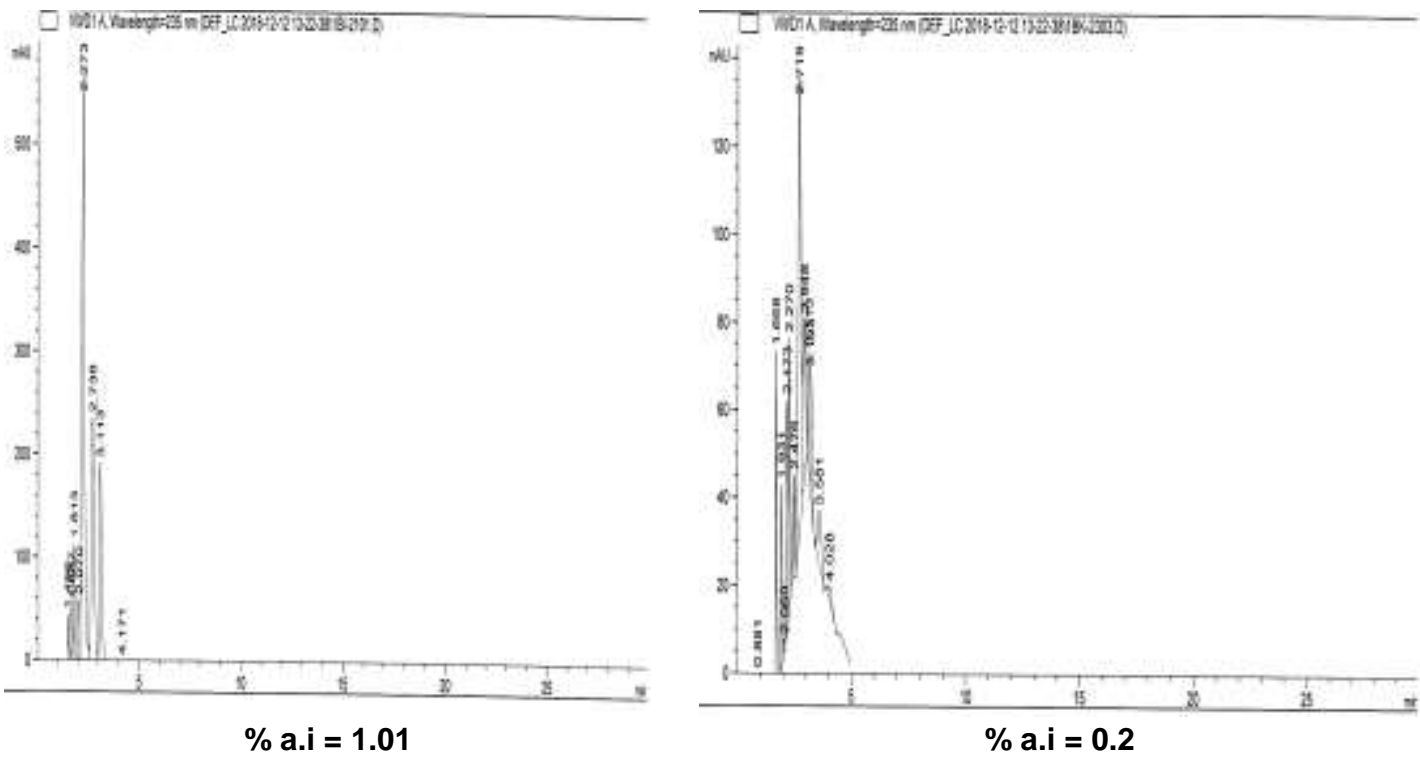

Fig. 12. HPLC Chromatogram of Abamectin Power.

Fig. 13. HPLC Chromatogram of Super vertimic.
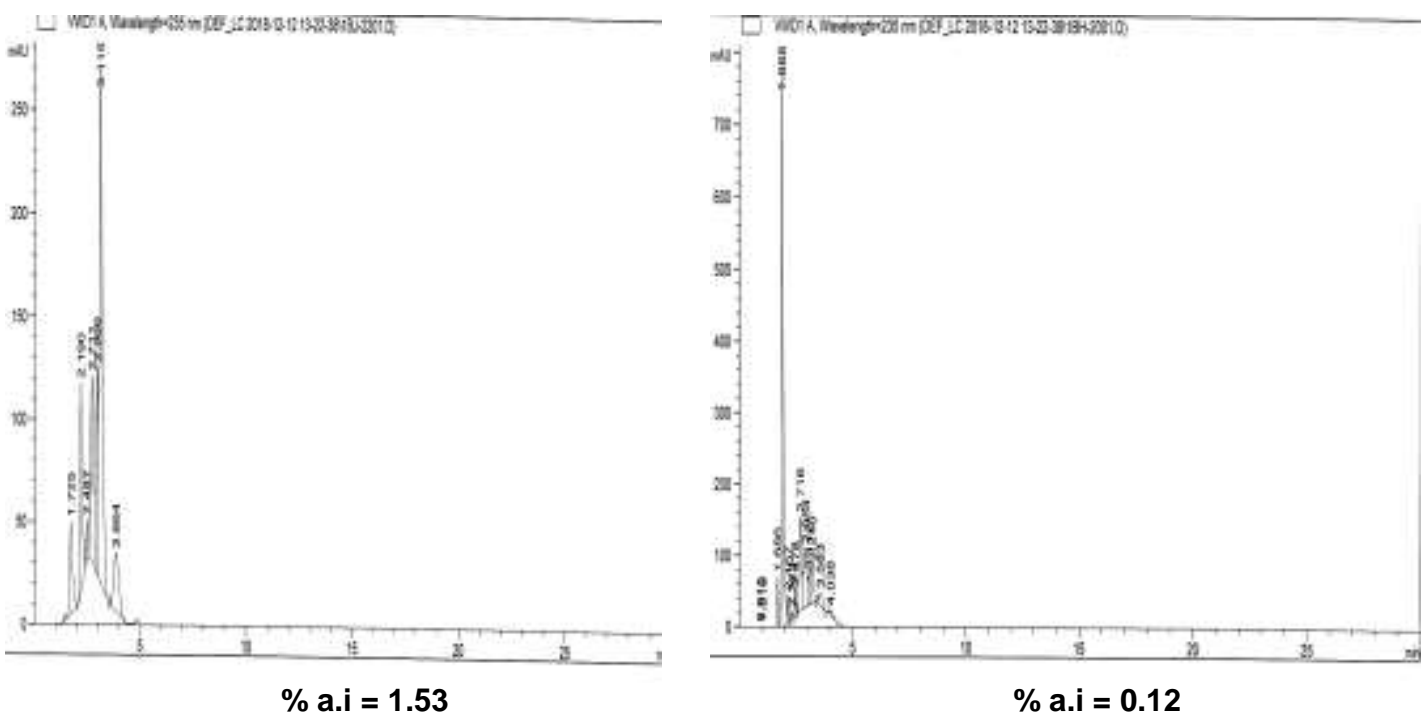

Fig. 14. HPLC Chromatogram of Tinam.

Fig. 15. HPLC Chromatogram of Abamectine strela. 


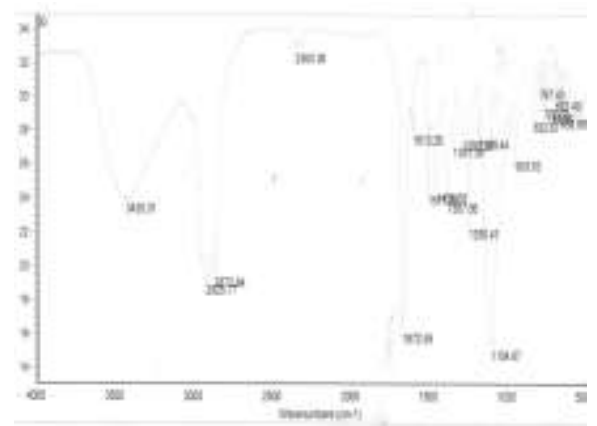

Fig. 16. FTIR spectrum of Abamectin super

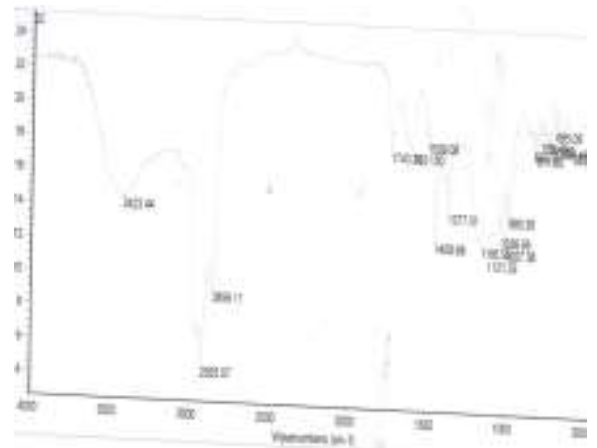

Fig. 18. FTIR spectrum of Komaktin Gold Plus

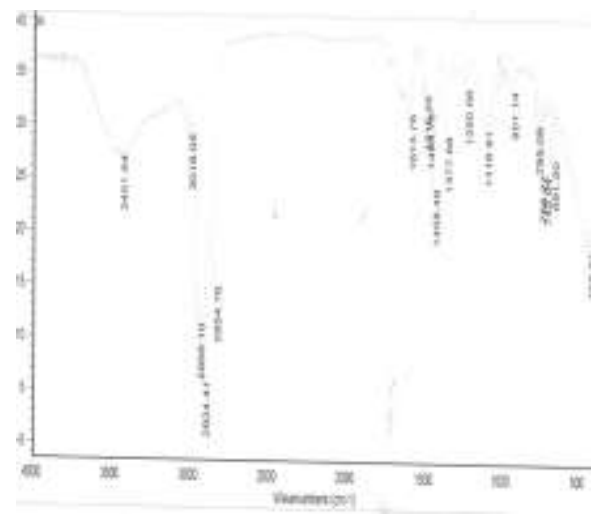

Fig. 20. FTIR spectrum of Super vertimic

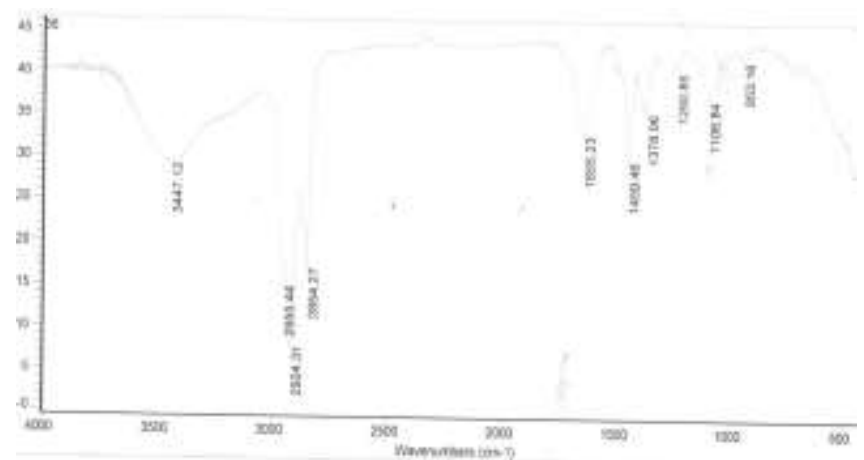

Fig. 22. FTIR spectrum of Abamectine strela

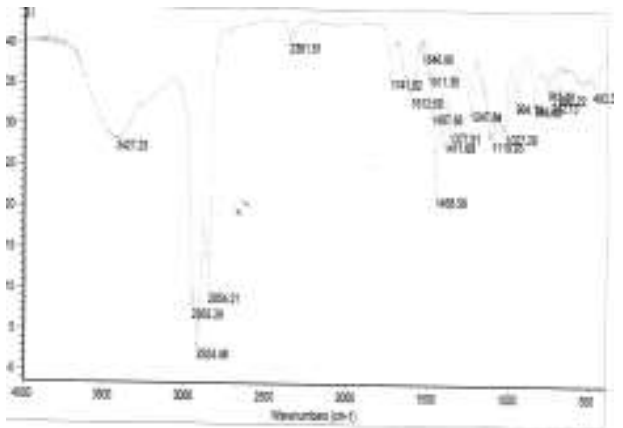

Fig. 17. FTIR spectrum of Farmactine.

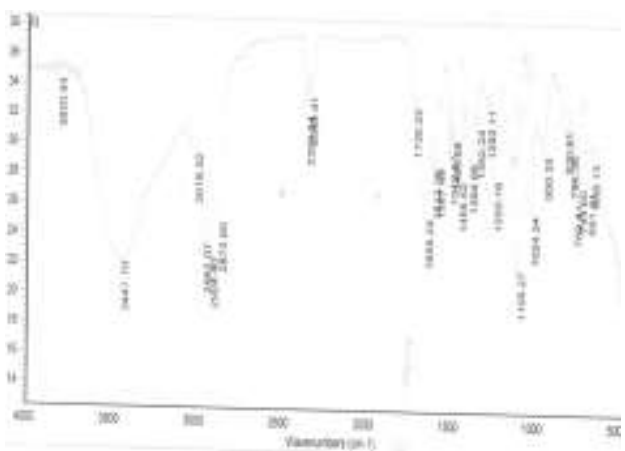

Fig. 19. FTIR spectrum of Abamectin power

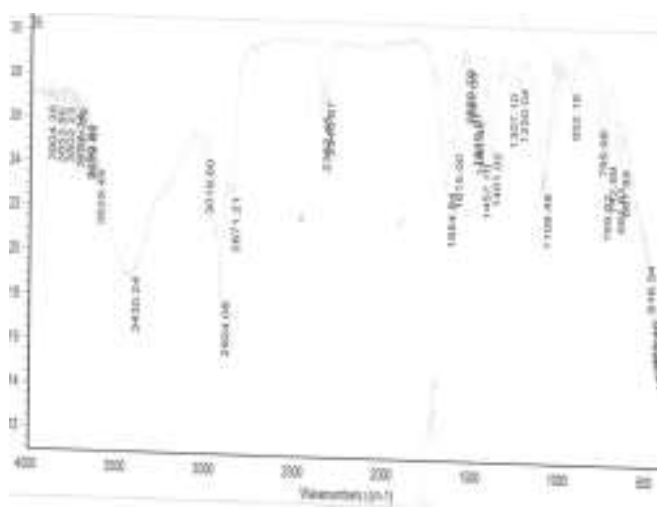

Fig. 21. FTIR spectrum of Tinam 


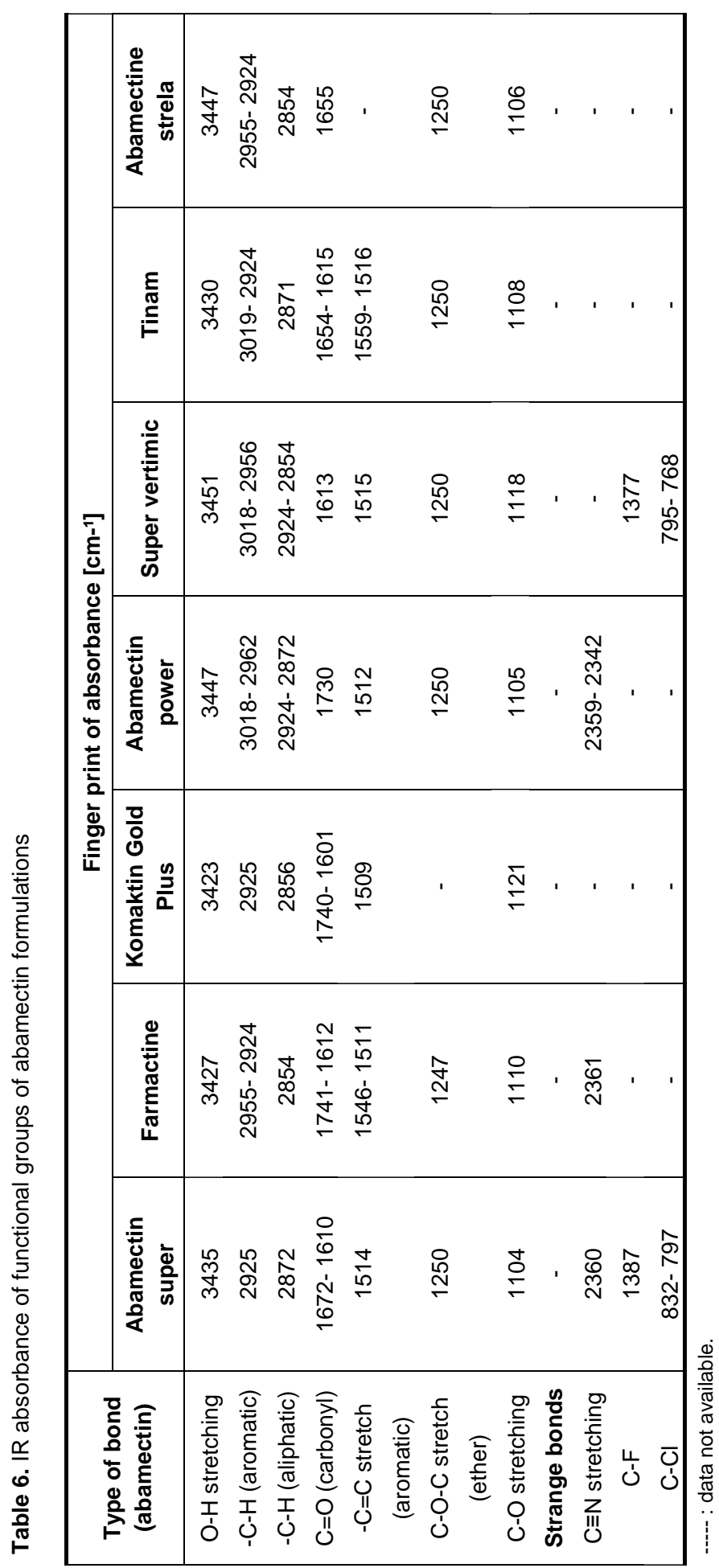




\section{REFRENCES}

Agrochemicals Market by Type - Global Trends \& Forecast to 2020, http://www.marketsandmarkets.com/MarketReports/globalagro-chemicals-market-report-132.html

Aldridge W.N., Miles J.W., Mount D.L. and Verschoyle R.D. 1979. The toxicological properties of Impurities in Malathion. Agric. Toxicol. 42, 95-106.

CIPAC Hand book MT 18.1. 1995. Preparation of Standard Waters A to G (MT 18.1.1 to 18.1.7), Vol., F, pp. 59-63.

CIPAC Hand book MT 36.3 1995. Emulsion characteristics of Emulsifiable Concentrate, Vol., F, pp. 108-109.

CIPAC Hand book MT 46.3 1995. Accelerated Storage Procedure, Vol., F, pp. 148-150.

Crop Protection Chemicals Market - Growth, Trends, and Forecast (2019 - 2024)

European Commission DG Health and Food Safety 2015. Ad-hoc study on trade of illegal and counterfeit pesticides in the UE.

FAO Specification and Evaluation for Agricultural Pesticides 2010. Manual on development and use of FAO and WHO specification for pesticides. Second Revision of the First Edition. Available only on the Internet.

Fishel F.M. 2008. Counterfeit Pesticides for Your Pet. PI-172. Gainesville: University of Florida Institute of Food and Agricultural Sciences. http://edis.ifas.ufl.edu/PI208 (February 2018).

Karasali H., Kasiotis K.M., Machera K. and Ambrus A. 2014. Case study to illustrate an approach for detecting contamination and impurities in pesticide formulations. J. Agric. Food Chem. 62, 11347-11352.

Karasali H. 2015. Counterfeit and illegal pesticides: strategies for addressing the issue in the analytical laboratory Pesticides manual, (2003).

Pesticide Regulation EPA, 1997. Notice 94(4),.

Rocky R. 2015. Counterfeiting and the Illegal Trade in Pesticides and Crop Protection Products. (Anti-counterfeit Project Manager International Conference Falsification).

Silverstein R.M., Clayton G. and Morrill C. 1991a. Spectrometric identification of organic compounds, $5^{\text {th }}$ edition, Infrared Spectrometry, Chapter three. 5(3), 91-142. 


$$
\begin{aligned}
& \text { جهاد مسعد خطاب1" - ولاء محمد السيد2 - عطا الله محمد } 1 \text { - محمد إبراهيم عبد المجيد2 }
\end{aligned}
$$

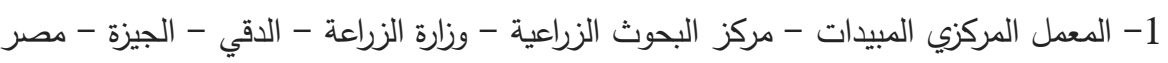

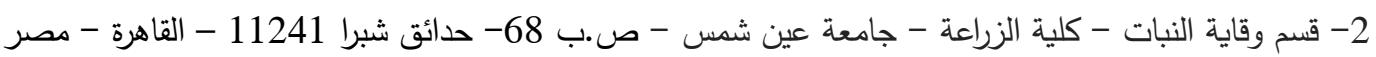

*Corresponding author: gehad capl@yahoo.com

Received 17 November, 2019

\section{Accepted 28 October, 2020}

و0.12\% على التوالي. لم تحتوي عالتهة واحدة على Abamectin وكانت العينة (Farmactine) ضمن الحدود المقبولة (Tinam) GC-MS

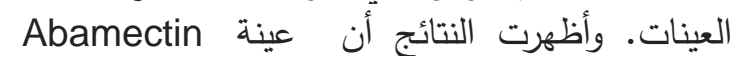
تحند Lambda cyhalothrin) تحتوى على Super 29.512 دقيقة) و عينة Farmactine عند 28.634 دقيقة) و عينة Fenpropathrin) Abamectin Power 16.088 دقيقة و Cypermethrin دقيقة) وعينة Super Vertimic تحتوى على Lambda عند 23.916 دقيقة و تحتوى Fenpropathrin) cyhalothrin Abamectine g Tinam gomaktin Gold Plus Strela الاستحلاب قبل وبعد التخزين مطابق في 4 عينات هي الخى ،Farmactine ،Abamectin super)

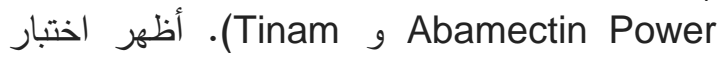
الاستحلاب قبل وبعد التخزين عدم التطابق في عينتين Abamectine و Super verticic Komaktin Gold Plus قبل التخزين مطابقًا وغير مطابق بعد التخزين.

الكلمات المفتاحية: المبيدات المقلدة، المبيدات غير المئرئ المشروعة وغير القانونية، أبامكتين، مطياف الكتئة الكتلة، الأشعة تحت الحمراء، الخواص الطبيعية
الهدف من هذه البحث إلقاء الضوء على وضع غش المبيدات فى السوق المصنرى عن طريق رصد البحن مبيد

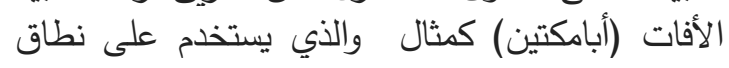

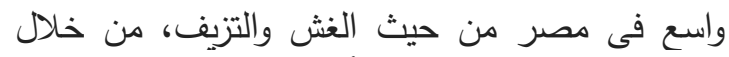
دراسة وتحليل مستحضرات أبامكتين (سبع عينات) تم الترن جمعها من السوق المصرية. تمت دراسة المبيدات المزيفة المينة

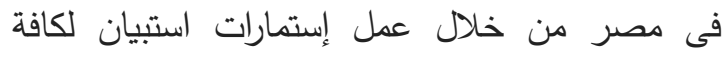

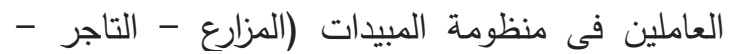
الباحثين فى قطاع المبيدات). أظهرت النتائج التي تم تمبن

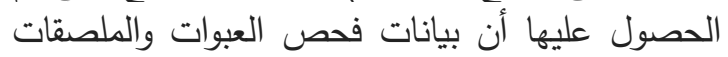
تشير إلى أن ثلاث عينات لم يتم تسجيلها من خلال لجنة التبات

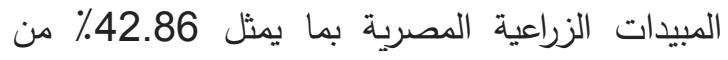
إجمالى العينات المختبرة. المنتجات غير المسجلة هي Super Vertimic, Komaktin Gold Plus Abamectine Strela, ثلاث عينات لها رقم تسجيل مستحضرات أخرى مسجلة بالفعل في وزارة الزراعة و هي تلات تئ Farmactine, Abamectin Super و المنتج الأخير power .Abamectin (Tinam) له رقم التسجيل الصحيح (رقم 1391) وهو نفس الرقم المستخدم لتسجيله في وزارة الزراعة. كانت النسبة المئوية المثية

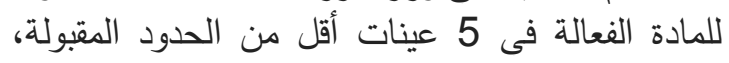

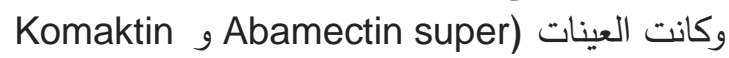
Super, Abamectin Power, Gold Plus (Abamectine strela و vertimic الفعالة بها هى 1.416 , 0.64 , 1.01 , 0.2 